\title{
The Political Economy of International Monetary Policy Coordination
}

\section{Citation}

Frieden, J.A., and J.L. Broz. 2013. “The Political Economy of International Monetary Policy Coordination." In Handbook of Safeguarding Global Financial Stability, ed. Gerard Caprio, 81-90. Boston, MA: Elsevier. doi:10.1016/b978-0-12-397875-2.00003-9.

\section{Published Version}

doi:10.1016/b978-0-12-397875-2.00003-9

\section{Permanent link}

http://nrs.harvard.edu/urn-3:HUL.InstRepos:33490995

\section{Terms of Use}

This article was downloaded from Harvard University's DASH repository, and is made available under the terms and conditions applicable to Open Access Policy Articles, as set forth at http:// nrs.harvard.edu/urn-3:HUL.InstRepos:dash.current.terms-of-use\#OAP

\section{Share Your Story}

The Harvard community has made this article openly available.

Please share how this access benefits you. Submit a story.

Accessibility 
$<1$. Title Page $>$

The Political Economy of International Monetary Policy Coordination

\author{
Jeffry A. Frieden \\ Department of Government \\ Harvard University \\ 1737 Cambridge St. \\ Cambridge, MA 02138 \\ U.S.A \\ tel. 617-496-2386 \\ email: jfrieden@harvard.edu \\ and \\ J. Lawrence Broz \\ Department of Political Science \\ University of California, San Diego \\ 9500 Gilman Dr., 0521 \\ La Jolla, CA 92093-0521 \\ U.S.A \\ tel. 858-822-5750 \\ email: jlbroz@ucsd.edu
}


$<2$. Name and affiliation page $>$

Jeffry A. Frieden

Professor

Department of Government

Harvard University

1737 Cambridge St.

Cambridge, MA 02138

U.S.A

J. Lawrence Broz

Associate Professor

Department of Political Science

University of California, San Diego

9500 Gilman Dr., 0521

La Jolla, CA 92093-0521

U.S.A 
$<3$. Table of Contents $>$

1. Introduction

2. The Potential Gains from International Coordination

3. The Problem: Exchange Rate Externalities

4. Exchange Rate Coordination: Motivation and Modalities

5. Conclusion 
$<4$. Keywords $>$

Anti-dumping

Bank for International Settlements (BIS)

China, currency policy

Consultative Group on Exchange Rate Issues (CGER)

Coordination, international monetary policy

Coordination, exchange rates

European Monetary System (EMS)

Exchange rates

Externalities, international

International Monetary Fund (IMF)

Misalignments, exchange rate

New Open-Economy Macroeconomics

Plaza Accord

Political economy

Protectionism 


\section{$<6$. Synopsis $>$}

The economic rationale for international monetary policy coordination is not strong. This is the conclusion, not only of the traditional Mundell-Fleming literature, but also the more recent New Open-Economy Macroeconomics literature on international monetary coordination. Yet a broader political economy approach illustrates that national currency policy can impose non-pecuniary externalities on partner nations. This is especially the case with major policy-driven misalignments, which cannot easily be countered by other governments. For example, one country’s substantially depreciated currency can provoke powerful protectionist pressures in its trading partners, so that exchange rate policy spills over into trade policy in potentially damaging ways. Inasmuch as one government’s policies create these sorts of costs for other countries, there is a case for global governance. This might include some institutionalized mechanism to monitor and publicize substantial currency misalignments. 
$<7$. Body $>$

\section{Introduction}

Exchange rates have been the focus of a great deal of international attention over the past two decades. Spectacular currency crises in emerging markets have thrown whole regions into economic and political turmoil. Major countries have accused each other of purposely manipulating their currencies, leading to acrimonious disputes that implicate broader economic ties. Questions have been raised about the future role of the dollar and the euro as international currencies. Yet despite these problems, the consensus academic view is that the economic rationale for international monetary policy coordination is not strong.

Especially in the context of the global "subprime" crisis that began in 2007, the problems and prospects of international monetary coordination warrant more scholarly and policy attention. It would be particularly useful to have a clearer understanding of the implications of the actions of the principal financial centers, as opposed to small open economies whose global impact is limited. It would also be helpful to explore the conditions under which the major powers could arrive at a collaborative solution to problems of monetary coordination, one that would not impose unacceptably asymmetric costs on participants. We also need a clear picture of the implications of monetary coordination among the major monetary authorities for countries elsewhere, both in times of crisis and in more normal times. The view that international monetary policy coordination is undesirable or infeasible, or both, has left us with too little understanding of what it might indeed entail. And yet, especially in the context of recent problems, all these issues deserve much more focused analytical attention. 
We begin with a brief discussion of the status of the literature on international monetary coordination. We then consider whether the lack of international monetary coordination among major powers is a source of uncertainty and instability in the world economy, and whether the world would be better off with a more encompassing governance structure to manage international monetary relations. The rationale for greater coordination hinges on the extent to which national exchange rate policies impose negative externalities on other countries. This provides a justification for cooperative action to internalize - and reduce - such externalities, and for an institutionalized mechanism to encourage such coordination. We then assess both the feasibility of such institutionalized coordination, and some specifics of how it might work.

\section{The Potential Gains from International Coordination}

The rationale for international policy coordination stems from the potential external effects that independent domestic policy actions can have on other countries. For example, when one country loosens monetary policy to stimulate domestic demand after a global shock, it will result in a depreciation of the exchange rate, which can adversely affect the prospects of other countries by reducing demand for foreign goods. This is an example of a negative externality, commonly referred to as a "beggar thy neighbor” policy because the stimulus comes at the expense of other countries. When other countries engage in the same policy, the policies cancel each other out, resulting in excessive inflation but no gain in output. The potential role for international coordination is to limit such counterproductive policy externalities. 
The issue of external effects has become more prominent as the world economy has become more integrated in recent years. This is because since the size of the externalities depends critically on the extent of economic integration between economies. If goods markets are not well integrated (i.e., exports are but a small fraction of a country’s total output), a currency depreciation will have a negligible impact on domestic production, and the international implications of the policy just won't matter very much. Likewise, if financial markets are not well integrated (i.e., capital does not flow readily in or out of a country in response to interest rate differentials), then monetary policy will not have a large effect on exchange rates or on foreign demand for domestic goods.

Given the pace of globalization in recent years, it is all the more surprising that the consensus academic position is that the gains from international coordination on monetary policy are negligible at best, and possibly even counterproductive. This position — that an inward-looking policy is approximately optimal and there is not much to gain from policy coordination-has persisted for nearly 40 years, even though national economies have become more closely integrated over that span of time.

In the 1970s and 1980s, strategic models were introduced to provide a theoretical rationale for policy coordination. Formal game theoretic models showed that policy bargains could be found that left some countries better off without others being worse off, in terms of their own policy objectives. The key insight was that coordinating policies to internalize the externalities could lead to higher welfare for all. While such models justified international coordination from a theoretical point of view, empirical studies from the 1980s revealed that the benefits of coordination were quantitatively small, compared to measurement error in the data and other metrics. This was somewhat 
intuitive since international integration was actually quite low at the time. The gains from monetary coordination across the major economic regions were not expected to be large because the United States, Europe, and Japan were still relatively closed economies in the early 1980s.

However, goods and financial markets have become more integrated since that time but the consensus position has changed very little. In fact, more recent work suggests that the benefits of coordination may actually decrease with globalization. This is the surprising conclusion of $21^{\text {st }}$ century work that incorporates the microfoundations of the New Open-Economy Macroeconomics.

These models include optimizing individuals, nominal rigidities, and a representative agent's utility function serving as the welfare metric for optimal policy. The role of government is to counteract distortions, such as wage stickiness and the possible failure of international consumption risk sharing, which prevent individuals from acting in their own interests. With perfectly integrated global markets, international monetary cooperation is redundant in this context, as inward-looking monetary rules can replicate the Pareto-efficient (flexible wage) allocation and global integration can help insure against country-specific shocks. For example, if an individual country suffers a fall in production, the scarcity of domestic goods relative to foreign goods induces a rise in price of domestic goods. This change in relative prices can compensate domestic agents for the smaller quantity of domestic goods they have to consume and export, as they will be able to import more foreign goods for the smaller quantity of domestic exports. The result is that they enjoy a level of consumption and utility comparable to the foreign country. In short, integrated goods markets can do the job of pooling risk internationally 
and thereby leave policymakers free to focus on eliminating the sticky wage distortion. Counteracting the wage distortion, in turn, need not involve any international policy coordination because, unlike the beggar thy neighbor policy of manipulating exchange rates, policymakers mimic the flexible wage outcome by manipulating the domestic labor market.

The implication of this research is that there is little need for institutionalized global cooperative mechanisms to coordinate national monetary policies. Rather, the best solution lies in having each individual country keep its own house in order and maintain a stable domestic price level. In fact, improvements of monetary policy institutions at the domestic level, conjoined with the further integration of world markets, may render international cooperative schemes superfluous. ${ }^{1}$

A limitation of this work is that the gains from cooperation are analyzed entirely within the macroeconomic realm. For tractability, monetary policies do not spill over into other domains, like trade policy, in these models. In the next section, we discuss how monetary policy may generate international spillovers outside of the macroeconomic realm, for political economy reasons.

\footnotetext{
${ }^{1}$ The strong conclusion about the lack of gains from international coordination has stimulated a great deal of new research on the sources of coordination gains. For example, the gains from coordination may be related to the degree of exchange-rate passthrough. Policy coordination may also produce welfare gains if the international financial markets are incomplete, if policymakers have imperfect information, and if domestic shocks are not perfectly correlated across countries.
} 


\section{The Problem: Exchange Rate Externalities}

Any argument for explicit collaboration among national governments rests on the presumption that purely national policymaking can produce collectively sub-optimal results. If national governments acting in their own self-interest adopt policies that are best for them and for others, then there is no scope for coordination to improve welfare. With respect to exchange rate policy, many analysts believe that the best outcomes will be obtained simply if individual governments adopt responsible macroeconomic policies, in their own self-interest. While at some level this is true, almost by definition - who could oppose responsible policies? - it is incomplete, and may lead to incorrect conclusions. In particular, the view neglects the implications of a theoretically grounded analysis of the political economy of macroeconomic policy.

An insistence that all that is necessary for optimal global policy outcomes is sensible national policy misses two important points, both relevant to international coordination. First, whatever theory may say about aggregate welfare, governments typically face political pressures to satisfy particular groups in the population with policies that deviate from whatever the textbook welfare-maximizing ideal may be. These politically driven policies can have a negative impact on other countries; and coordination among nations can help mitigate the effects of such particularistic policies. Second, even government policies that are optimal from a national standpoint (whether in purely economic or political-economy terms) may impose externalities on other countries, whether due to purposive strategic behavior such as free riding, or due to the fact that the external effects are not internalized. 
This logic is widely accepted in many arenas, such as trade policy. Each country is, under most circumstances, best served by unilateral liberalization. ${ }^{2}$ Yet governments face powerful political incentives to erect or maintain protective barriers, despite the fact that this imposes efficiency costs on the national economy, and on the nation's trading partners. In this context, scholars have argued that a wide variety of international trade institutions can help governments cooperate to improve the welfare of all concerned. For example, the WTO institutionalizes reciprocity, thereby empowering domestic interests (especially exporters) who can oppose protectionist pressures; and its dispute settlement mechanism helps resolve complaints about national policies while reducing the risk of unilateral retaliation. There seems little doubt that the institutions of international trade perform the transactions cost-reducing role scholars expect from an international governance structure, and do so in ways that increase the likelihood of a cooperative trade policy outcome and a joint increase in welfare.

In other words, there are at least two objections to the view that international coordination is unwarranted because all that is necessary is that governments adopt nationally appropriate policies. First, we can reliably anticipate that government policy will often be driven by motives other than aggregate social welfare - such as getting

\footnotetext{
${ }^{2}$ The exception is in the case of a country that can use its market power to improve its terms of trade by an optimal tariff. While there may be evidence for the relevance of optimal tariff considerations for some aspects of trade policy, it seems clear that the structure and level of protection in most nations responds to political economy pressures as well.
} 
reelected, satisfying powerful domestic interest groups, or achieving non-economic goals. In this context, the uncoordinated pursuit of what is "nationally appropriate" in a political-economy sense may lead to outcomes that could be improved upon by inter-state coordination. Second, there are many instances in which national governments may not fully internalize the negative (and positive) externalities created by their own policies. These two factors are indeed the justification for virtually all international organizations. They can be combined in the following argument: the uncoordinated pursuit of national policies, determined in political-economy equilibrium, can create negative externalities for other nations, and thus can lead to a collectively inferior outcome.

In applying this reasoning to international monetary relations, the first step is to assess the extent to which this actually might pertain to national exchange rate policies. After all, if a government manipulates its currency, pulling it away from a defensible or realistic exchange rate, the principal effects will be felt at home. And it might be argued that to the extent that the movement of one country's currency imposes costs on another country, the latter can simply reverse the charges by counteracting the currency movement. Nonetheless, in currency affairs, as elsewhere, there are varieties of external effects that go beyond the impact on the national economy and national economic actors, and for which a unilateral response is either not possible or not desirable.

Some might see currency volatility as a strong argument for international coordination. The strongest case for this is that it dampens incentives for private actors to engage in welfare-improving cross-border (or cross-currency) trade, investments, and payments. Certainly there is plenty of evidence that currency stability encourages international economic exchange; and this in turn implies that the world would be better 
off were volatility reduced. There are at least a couple of problems with this. First, while exchange rate volatility may be a serious problem for the international economy, it is not really the result of uninternalized externalities. Volatility is often the result of national policy, to be sure; but its negative effects are almost entirely domestic - national traders, investors, borrowers, and others are deprived of market opportunities. To the extent that the decision to allow a national currency to move around is made by the government, it presumably takes into account the negative impact of this volatility on domestic economic actors. The second argument against concerted international action to reduce currency volatility is that this volatility may to some extent represent a desirable flexibility in exchange rates. For example, a currency movement to correct an unsustainable misalignment is not a bad thing. The problem typically discussed is “excess volatility," but this is much more likely to be the result of the operation of modern currency markets than the result of government policy. Market actors are probably at the root of much of today's "excess volatility,” and it is not clear that cooperative government intervention to restrict foreign exchange markets would be a good thing. So the argument for international coordination to reduce exchange rate volatility is relatively weak.

Exchange rate misalignments, on the other hand, can be the source of substantial problems for other nations and for international economic relations more generally. A government may purposely keep its currency relative weak, in the expectation that a depreciated currency will stimulate exports (such policies cannot prevail forever, but there is strong evidence that the rate at which exchange rates converge toward PPP can be quite slow - certainly slow enough to allow such misalignments to have substantial 
effects on the real economy). Of course, a depreciated exchange rate has a negative effect on national purchasing power, but this is solely a domestic matter in which the government has decided to trade off the welfare of exporters and import-competers, on the one hand, for that of consumers. However, a depreciated currency puts competitive pressure on the country's trading partners, and can stimulate protectionist sentiments abroad. The result may be to trigger commercial discord between countries, and even to endanger broader trade agreements.

Recent conflicts between the United States and China, indeed, illustrate the potential for a currency misalignment to provoke trade tensions. For years, there have been indications that the weak renminbi was inflaming Congressional protectionism, and these sentiments were only moderated when the dollar began to depreciate against other currencies. In an earlier era, the dramatic appreciation of the U. S. dollar in the early 1980s led to major protectionist legislation in the U. S. Congress, and an unprecedented spike in complaints to the International Trade Commission: anti-dumping cases, for example, tripled from an annual average of 18 between 1979 and 1981, to an annual average of 56 between 1982 and 1984. These exchange rate-provoked conflicts have placed a significant strain on the international trading system, both in bilateral relations between the countries in question, and more generally inasmuch as they have called into question the commitment of major countries to the multilateral resolution of trade disputes.

In was not only in the early 1980s that exchange rates spilled into the trade arena: from the late 1970s to the present, protectionist activity in the United States has been positively related to the level of the real exchange rate. Figure 1 plots the association 
between the real effective exchange rate (REER) of the U.S. dollar and anti-dumping cases investigated by the United States International Trade Commission (USITC ) — the quasi-judicial Federal agency that conducts antidumping and countervailing duty investigations. These data clearly indicate that the number of anti-dumping cases investigated by the USITC increases with the appreciation of the U.S. dollar. The one outlier-1992 — is the exception that tests the rule. On July 8, 1992, the steel industry filed 47 separate anti-dumping petitions on various countries for four types of steel products. If we reduce these 47 cases to four-since this flurry of steel-related cases weren't really separate- the fit of this simple model improves to $\mathrm{R}^{2}=0.32$ from $\mathrm{R}^{2}=$ 0.21 .

$<$ Figure 1 near here $>$

This relationship is meaningful in a substantive sense as well. Simulating the effect of increasing the REER of the U.S. dollar by one standard deviation above its mean—a roughly 10 percent real appreciation —increases the number of anti-dumping cases filed at the USTIC by 10.7 cases per year (the 95 percent confidence interval ranges from 4.09 to 17.63 cases per year). Given that only 39.5 cases are filed per year on average, this is a very large effect.

Another set of examples of how national currency policy can affect other economic ties come from the interaction of regional currency relations and regional trade agreements. In January 1999, the Brazilian government allowed the real to float, which led to a very substantial depreciation of the currency. This came on the heels of a 
dramatic expansion of Brazilian-Argentine trade in the context of Mercosur, a trade agreement strongly favored by both governments. But the devaluation, and the overvalued peso associated with Argentina's currency board, provoked a flood of imports into Argentina: in the first eight months of 1999, Argentine imports of Brazilian textiles and footwear rose by 38 and 66 percent respectively. This in turn provoked protests from Argentine manufacturers, who forced the Argentine government to impose barriers on Brazilian iron, textiles, and paper. The Brazilians retaliated, complained to the WTO, and even threatened to dissolve Mercosur..

In Argentina, just as in the United States, the level of the exchange rate correlates positively with protectionist activity over time. Figure 2 plots the number of antidumping cases investigated by Argentina’s Comisión Nacional de Comercio Exterior (National Foreign Trade Commission) against the REER of the peso between 1995 and 2009. The positive relationship illustrates that when the peso appreciates against the currencies of major trading partners like Brazil, political pressure for trade protection intensifies. The most anti-dumping cases were initiated in 2000 and 2001, following the Brazilian devaluation and the spike in the REER of the peso. Moreover, the exchange rate appears to have a large substantive impact on anti-dumping investigations in Argentina. Simulating the effect of increasing the REER of the peso by one standard deviation (55.56) above its mean (147.93) results in 4.98 additional antidumping cases investigated by Argentina's trade commission (the 95 percent confidence interval for this estimate is 0.75 to 9.06 cases). Since the commission only investigates 16 cases per year, on average, this is a powerful (and statistically significant) result. 
$<$ Figure 2 near here $>$

The Mercosur crisis was reminiscent of an earlier episode in the European Monetary System (EMS). The 1992-1993 currency crisis in the EMS led to large devaluations of some EMS currencies. As a result, producers in countries whose currencies had been stable - in particular France and Germany - came under competitive pressures. This in turn led to domestic complaints about imports from the countries whose currencies had depreciated, which threatened the core commitments of the European Union (EU), especially in the wake of the completion of the single European market. This posed a stark choice for EU members: whether to retreat to more flexible exchange rates, which might jeopardize the single market, or to move forward to full monetary union, which would eliminate the problem of exchange rate variability altogether. Returning to more freely fluctuating exchange rates threatened to fuel a popular backlash against the single market, since currency depreciation seemed to confer an arbitrary competitive advantage on certain national producers. In this instance, the alleged undervaluation of some European currencies endangered other economic and non-economic agreements into which EU member states had entered.

Just as relatively depreciated currencies can create negative externalities for governments' trade relations, so can relative appreciated currencies cause problems. This is most clearly the case when a government's attempt to sustain an appreciated exchange rate that is widely regarded as misaligned leads to an attack on the currency that results in a contagious currency crisis. In fact, most medium-to-large real appreciations are reversed by nominal devaluations. While there are continuing debates over the precise 
sources and nature of devaluation crises such as those in Latin America in 1994-1995 or in East Asia in 1997-1998, there is a strong case to be made that in both instances misaligned national currencies created the conditions for speculative attacks both on the initially misaligned currencies and on those of their regional neighbors.

While regional spillovers may justify regional coordination of exchange rate policies, the case for international coordination rests with currency crises that spread across regions to affect nations that are very distant geographically and economically from the originating country. Examples of this type of contagion include the spillover of the crisis in Hong Kong to Mexico and Chile in 1997, and the transmission of the Russian crisis of mid-August 1998 into Mexico and other Latin American countries. In these cases, and others, there were few trade and financial linkages between the country experiencing the initial crisis and the distant countries that subsequently were attacked; there were also few macroeconomic similarities that would suggest spillovers. These were cases of "pure contagion" in the sense that the spillover effects were unanticipated, or larger than expected, on the basis of the observable macroeconomic, trade, and financial interdependencies.

None of this is meant to imply that the actual policies adopted in these instances were inappropriate. Indeed, in most cases they were probably the best the governments in question could do. The United States did not actively attempt to strengthen the dollar after 1981; Brazil should have allowed the real to depreciate in 1999; the EMS members in 1992 should have devalued, and so on. But that is not the relevant question. The relevant question is: could these outcomes have been improved by international coordination? Could the United States and its principal partners have cooperated more 
organically before 1985 (when growing concern led to the Plaza Accord)? Could Brazil and Argentina have worked out a collaborative arrangement to allow both their misaligned currencies to depreciate? Could Germany and its EMS partners have developed a cooperative response to German unification? If so, could such coordination have moderated the currency misalignments, and mitigated their effects on trade and other policies?

The answer is a qualified yes. Strongly misaligned currencies create problems not just for their home countries but for their economic partners, and in some instances for regional or global economic relations more generally. Inter-governmental cooperation could in principle help avoid some of the problems that arise as a result. For while all these cases are different, they have certain features in common. In all instances, policies pursued by national governments concerned about domestic conditions created serious difficulties for other countries. In all instances, the difficulties gave rise to frictions that spilled over into - and typically were most significant for - the non-monetary realm, often trade policy. And this is not surprising. Exchange rate movements are effective substitutes for trade policy - a 10 percent devaluation is equivalent to a 10 percent tariff and a 10 percent export subsidy - but in most cases there is no international or bilateral check to such movements while there is to increasing trade barriers or export subsidies. A government that is constrained by international agreements not to slap on protective tariffs or proffer export subsidies can instead depreciate its currency and achieve much the same effect. Inasmuch as the former policies in the trade realm create negative externalities and thus provide scope for welfare-improving international coordination, the latter must as well. 
The precise nature of the externalities created may vary over time and across place. They would almost certainly include:

1. Artificially weak currencies to gain competitive advantage, which risk imposing costs on trading partners and threatening commercial cooperation.

2. Active policies to depreciate currencies in hard times for "competitive" reasons, which risk provoking a spiral of “competitive devaluations.”

3. Artificially strong currencies whose collapse threatens crisis contagion.

The next step is to consider how international coordination, and perhaps some form of international governance structure, might help alleviate the problems associated with this behavior.

\section{Exchange Rate Coordination: Motivation and Modalities}

Whatever theory may say about the desirability of international coordination, and international institutional innovation, they are only feasible if governments are motivated to move in that direction. There is some evidence that the time may be ripe for innovative measures to institutionalize international currency coordination.

The first indication of at least a latent interest in greater coordination is that policymakers mention it on a regular basis. While actions speak louder than words, words are not irrelevant, and virtually every major summit meeting on economic issues has expressed a desire for coordination on currency issues. For example, the April 11, 2008 Statement of G-7 Finance Ministers and Central Bank Governors reads in part: “[T]here have been at times sharp fluctuations in major currencies, and we are concerned about their possible implications for economic and financial stability. We continue to 
monitor exchange markets closely, and cooperate as appropriate” (available at http://www.ustreas.gov/press/releases/hp919.htm). So there is at least a verbal recognition of the desirability of coordination.

This recognition includes arguments in favor of more active international monetary coordination from some of the world's leading academic experts on the subject. William Cline and Morris Goldstein have been explicit about their view that exchange rate coordination is highly desirable. Barry Eichengreen has made similar arguments, both in general and with respect to East Asia. It is not inconsequential that these highly respected analysts have been outspoken in their views.

There has also, in fact, been some official action in addition to all the many words. A few times in the past 25 years, major governments have felt strongly enough about the global implications of national currency policies to try to work out collaborative agreements. The best-known are the Plaza and Louvre accords of 1985 and 1987, respectively, meant to address problems associated with the appreciation of the U. S. dollar in the early and middle 1980s, and its aftermath. Most recently, the United States and China have engaged in “quiet diplomacy” over China’s currency policy, which Fred Bergsten has likened to an off-budget export and job subsidy that has evaded all international sanctions to date. Although skeptical that the renminbi is significantly undervalued, Ronald McKinnon also supports greater G2 (U.S-China) coordination, on the grounds that exchange-rate coordination between the world's two largest economies could help limit the devaluation tendencies of other nations around the world.

Perhaps due to the imbroglio over the value of the renminbi, the member states of the International Monetary Fund (IMF) have recently expanded the IMF's mandate quite 
substantially to include regular surveillance and reporting on exchange rate issues. Of course, the IMF's original activities were heavily oriented toward the exchange rate regime, but with the end of the Bretton Woods system this fell into disuse. In the aftermath of currency crises and substantial misalignments, however, the Fund has been under substantial pressure to reinvigorate this dimension of its activity. The IMF's Independent Evaluation Office produced a series of reports that were highly critical of the Fund's actions in currency crises, culminating in a critical broad review of the IMF's exchange rate policy advice published in May 2007. In June 2007, the Executive Board adopted a new “Decision on Bilateral Surveillance Over Members' Policies,” which was intended to strengthen the role of the IMF in overseeing national currency policies (the decision is available at http://www.imf.org/external/np/sec/pn/2007/pn0769.htm\#decision).

Neither of these initiatives, among G-7 members or at the IMF, has been particularly productive, although the IMF endeavor is too new to judge fairly. Nonetheless, their existence is evidence of at least a superficial commitment to do something about the misalignment and volatility of currencies. So there is some evidence of a desire on the part of major governments to work out more fully established mechanisms to cooperate in the determination of national currency policies.

There is, nonetheless, room for skepticism about the international political feasibility of such plans. Perhaps the most powerful argument that nothing substantial is likely to happen is a simple one: none of the major actors has an incentive to change the situation. The United States and the euro zone, in particular, can simply impose their exchange rate policy preferences on others. This gives them little reason to want any 
movement away from the status quo. While there is undoubtedly a lot of truth to this, it is also the case the American and European policymakers do sometimes find themselves facing politically difficult interactions with other governments (as with China); and that American and European policymakers sometimes find themselves at loggerheads with each other. This implies that even for the two great currency powers, there may be room for improvement in the context of a more cooperative international monetary order.

The problem is more general, for it may be that those monetary authorities with the least incentive to act are those whose actions would be most helpful. The governments of the world's principal financial centers (including the European Central Bank) have both the greatest potential to impose costs on others and the greatest ability to ignore those costs. The central position of the major currencies in international trade and payments mean that the policies of the home governments of these currencies have an impact far beyond their borders. At the same time, precisely because the major currencies are issued by governments (or supranational authorities such as the European Central Bank) with responsibility for large and relatively closed economic areas, they may have little incentive to take into account the effects of their actions beyond their borders. Policymakers in Washington, Tokyo, or Frankfurt might simply regard the negative externalities they create as less important than the domestic political pressures to which they have to respond. This reality is compounded by the fact that whatever arrangement might be adopted would almost certainly privilege one currency over another, and the major financial powers are unlikely to be of one mind about which currency should be central. An even more encompassing observation, in the tradition of modern Political Economy, might be that it is difficult to imagine the incentives for 
support-maximizing politicians to undertake policies that impose concentrated and visible costs on constituents in order to reap diffuse and hard-to-observe benefits. This may in fact help explain why there has been so little international monetary coordination. Nonetheless, especially in times of crisis, policymakers may find it in their own interest to seek out innovative measures - including those involving international coordination in order to reduce the impact of severely negative economic shocks on politically relevant constituencies. Whether conditions are of this type remains to be seen.

Setting aside these reservations for a moment, what might mechanisms to encourage coordination in exchange rate policies involve? The first question to answer is what their goals should be. Here it seems clear that the principal purpose envisioned by most, and which the above discussion implies, is to avoid or reverse substantial currency misalignments. Inasmuch as undervalued currencies exacerbate inter-governmental tensions in trade and other policies, and inasmuch as overvalued currencies run the risk of subjecting other countries to contagious crises, international coordination should aim to reduce the incidence of these misalignments in exchange rates. While the goal of reducing currency volatility may also be relevant, there would seem to be somewhat less scope for that, given the ability of free-wheeling currency markets to affect short-term movements in exchange rates.

How, then, might international initiatives lead governments to alter their policies in a more cooperative direction? Certainly there is little or no scope for coercive measures in this, as in most other international economic relations. International institutions are strictly limited in their ability to enforce compliance with their directives on countries that join voluntarily. They can, however, help national governments 
converge on punishment strategies for countries that do not conform to accepted principles; and they can also provide information that can affect the behavior of private (and public) actors.

In this context, perhaps the most useful purpose for an international institution charged with monitoring exchange rates would be to make explicit, and public, a determination that a particular national currency was inappropriate, and perhaps unsustainably, misaligned. While some might argue that public identification of the misalignment of a particular currency by an international organization might impose some sort of psychic shaming costs on a government concerned about its reputation, this is unlikely.

A government has pragmatic reasons to be concerned about this sort of misalignment "badge of shame." Such a finding might be seen by currency markets as an indication of the likely future path of the country's exchange rate, prompting market actors to try to anticipate this movement. In this way, an institutional "finding" of overvaluation could prompt a sell-off of the currency and force the currency down. This is somewhat less likely in the case of an undervaluation, for governments find it easier to sterilize a run toward their currency than to defend against a run on it (this is reminiscent of the adjustment asymmetry between surplus and deficit countries). Nonetheless, a declaration of misalignment from a respected, circumspect, international organization would be almost certain to provoke a market response, which would tend to push the exchange rate in the "right" direction. Put differently, such a public announcement might serve to help resolve uncertainties about a government's true commitment to an exchange 
rate target zone, where the target was some generally accepted notion of a realistic real exchange rate.

In a sense, this sort of machinery would be analogous to the consensual establishment of target zones for all currencies. The difference is that the target would be one established by some independent authority; and presumably the bands would be quite wide - a currency typically needs to be at least 20 percent above or below some notional equilibrium exchange rate to be considered seriously misaligned. The IMF's Consultative Group on Exchange Rate Issues (CGER) has long worked on a variety of methods to assess exchange rates, with an eye toward identifying deviations from the rate necessary to obtain macroeconomic or external-account balance, or to come close to an equilibrium real exchange rate. In this context, public and explicit recognition by an authoritative and respected international institution that a currency was misaligned would go a step farther than anything currently existing.

A step even farther past this would be a norm, or a rule, that permitted countries faced with the impact of a recognized misalignment to act to protect themselves. This would be analogous to the right to impose trade sanctions granted by the WTO to winners in WTO disputes. In the case of a depreciated currency, the most likely corrective measure would be temporary trade barriers, although one would hope that the threat of such barriers would make their imposition unnecessary. Indeed, the fact that temporary protection would be permitted in the event of a recognized undervaluation could make the threat more credible. In the case of an appreciated currency, corrective measures might include capital or exchange controls targeted explicitly at the country, or 
anticipated commitments to coordinated intervention to reduce the threat of contagion if and when the currency were attacked.

Which international institution could be charged with this task of managing coordination in exchange rate policies? The IMF makes the most sense, given its historical commitment to monitoring exchange rate relations and its more recently redoubled effort in this regard. One problem is that the Fund has moved so far in the direction of a development-oriented agency that it might be difficult for Fund findings to have an impact on developed governments. The Bank for International Settlements (BIS) has maintained much of its credibility with advanced industrial countries. Perhaps, as in the sovereign debt realm, some collaborative effort by the IMF and the BIS might be most appropriate.

Whatever institution or mechanism was to embark on this difficult endeavor would need several things to maximize the likelihood of success:

1. A serious commitment from the monetary authorities of the major financial centers.

2. An internationally respected professional staff, at least of the caliber of the IMF and BIS research teams.

3. The political will, on the part of the participating states and the professional staff, to name names as necessary.

4. Consultation with the WTO, both the monitor trade-policy spillovers of currency policies, and to ensure that exchange rate-based trade policy measures are consistent with WTO principles. 
Whether any, let alone all, of these things will be forthcoming in the near future is highly debatable. But at least it should be debated. And the recent global financial turmoil makes the stakes that much higher. The incentives for countries to act unilaterally rise substantially in times of crisis; and the seriousness of the negative externalities unilateral action can impose also rises substantially. It is easy to imagine circumstances in which uncoordinated macroeconomic policies could seriously deepen a financial crisis. While the difficulties of coordination may be great, its desirability is almost certainly growing.

\section{Conclusion}

This essay makes the case for systematic inter-governmental cooperation on international monetary affairs. It argues that there are clear and present externalities associated with national exchange rate policies. Whatever one may believe about purely economic externalities in this realm, they are clearly present in a broader politicaleconomy sense.

Substantial currency misalignments create especially obvious negative externalities. An artificially depreciated currency creates powerful pressures for trade protection in trading partners, and can threaten the very structure of international commercial relations. An artificially appreciated currency risks “infecting” other countries in the event of a contagious currency crisis. We think that the case for the existence of these "spillovers" is clear; that the scope for non-cooperative strategic behavior in the currency realm is also clear; and that the intellectual case for international coordination is similarly clear. Scholars can help illuminate the options available to 
national governments, especially in times of crisis. Whether the intellectual clarity of the case is accompanied by incentives for policymakers to act is another matter. 
$<$ 8. Further Reading $>$

\section{Further Reading}

Bergsten, C.F. (2006). The U.S. trade deficit and China. Testimony Before the Hearing on US-China Economic Relations Revisited, Committee on Finance, United States Senate, March 29. Available at http://www.iie.com

Carranza, M. (2003). Can Mercosur survive? Domestic and international constraints on Mercosur. Latin American Politics and Society 45, 67-103.

Chung, D. K. and Eichengreen B. (eds.) (2007). Toward an East Asian exchange rate regime. Washington, DC: Brookings Institution.

Cline, W. (2005). The case for a new Plaza Agreement. Policy Brief in International Economics 5-4. Washington, DC: Institute for International Economics.

Edwards, S. (1989). Real exchange rates, devaluation and adjustment: exchange rate policy in developing countries. Cambridge, Mass.: MIT Press.

Eichengreen, B. (2004). What macroeconomic measures are needed for free trade to flourish in the western hemisphere? Latin American Politics and Society 46, 1-27. 
Frieden, J (2009). Avoiding the worst: international economic cooperation and domestic politics. VoxEU (February 2). Available online at http://www.voxeu.org

Goldstein, M. (2006). Exchange rates, fair play, and the “Grand Bargain.” Financial Times, April 21.

McKibbin, W. J. (1997). Empirical evidence on international economic policy coordination. In Fratianni, M., Salvatore, D., and von Hagen, J. (eds.) Handbook of comparative economic policies: macroeconomic policy in open economies. vol. 5, pp 148-176. Westport, CT: Greenwood Press.

McKinnon, R. I. (2009). Solidifying a new G2. The International Economy 23, 27-29.

Obstfeld, M., and Rogoff, K. (2002). Global implications of self-oriented national monetary rules. The Quarterly Journal of Economics 117, 503-536.

Oudiz, G. and Sachs, J. (1984). Macroeconomic policy coordination among the industrial economies.” Brookings Papers on Economic Activity 1, 1-75.

Research Department, International Monetary Fund (2006). Methodology for CGER exchange rate assessments. Washington: International Monetary Fund. 
$<10$. Figures $>$

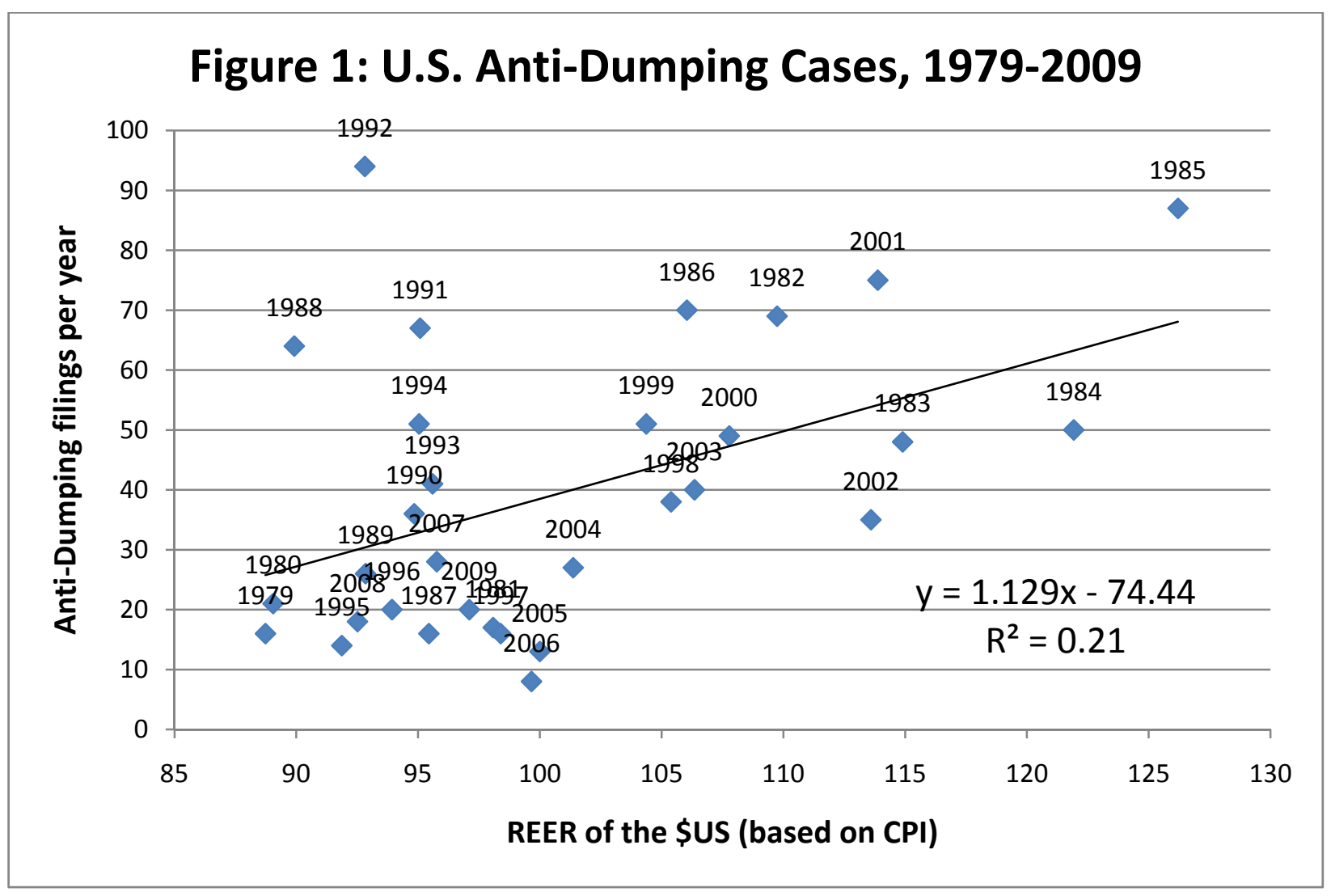

Notes: The base year for the REER index is 2005. The REER data are from the Bank for International Settlements, available at http://www.bis.org/statistics/eer/index.htm. Antidumping data are from Chad P. Bown, (2010) "Global Antidumping Database," available at http://econ.worldbank.org/ttbd/gad/ 


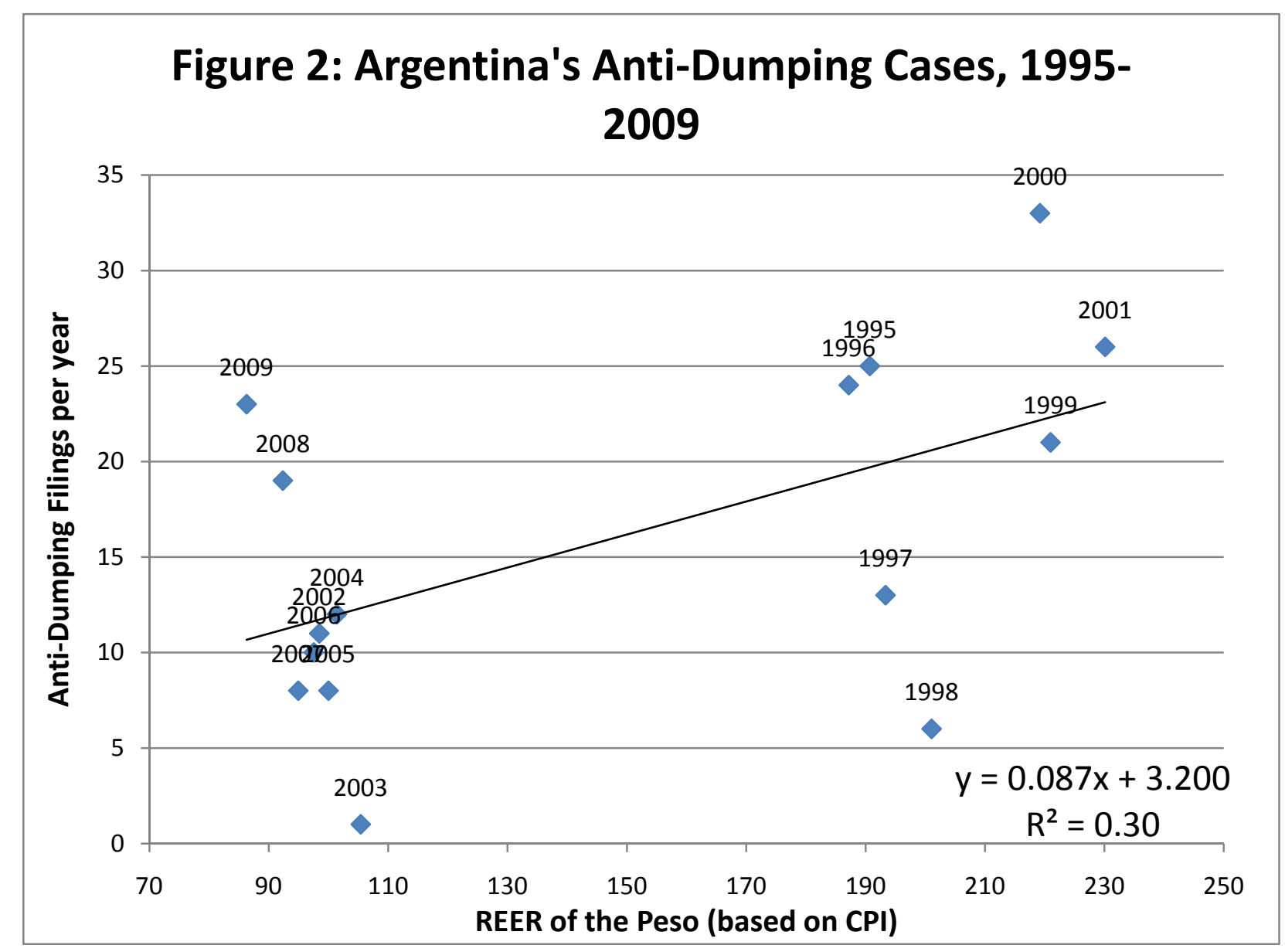

Notes: The base year for the REER index is 2005. The REER data are from the Bank for International Settlements, available at http://www.bis.org/statistics/eer/index.htm. Antidumping data are from Chad P. Bown, (2010) “Global Antidumping Database,” available at http://econ.worldbank.org/ttbd/gad/ 
< 13. Brief Biographies >

Jeffry A. Frieden

J. Lawrence Broz is Associate Professor of Political Science at the University of California, San Diego. Professor Broz has held faculty appointments at Harvard University and New York University and received his Ph.D. from the University of California, Los Angeles in 1993. He is the author of International Origins of the Federal Reserve System (1997), and his recent articles have appeared in a number of top journals, including International Organization, the American Journal of Political Science, and the Annual Review of Political Science. His current research focuses on the institutions of monetary and financial policymaking--such as central banks and international financial institutions. 